\title{
Estimation of Clinical, Immunological and Virological Failure of First Line Antiretroviral Treatment in Kinshasa, Democratic Republic of Congo
}

\section{Erick Ntambwe Kamangu}

Service of Molecular Biochemistry, Department of Basic Sciences, Faculty of Medicine, University of Kinshasa (UNIKIN), Kinshasa, Democratic Republic of Congo

Email: erick.kamangu@unikin.ac.cd

How to cite this paper: Kamangu, E.N. (2018) Estimation of Clinical, Immunological and Virological Failure of First Line Antiretroviral Treatment in Kinshasa, Democratic Republic of Congo. Open Access Library Journal, 5: e4560. https://doi.org/10.4236/oalib.1104560

Received: April 2, 2018

Accepted: May 19, 2018

Published: May 22, 2018

Copyright $\odot 2018$ by author and Open Access Library Inc.

This work is licensed under the Creative Commons Attribution International License (CC BY 4.0).

http://creativecommons.org/licenses/by/4.0/

\begin{abstract}
Background: The prevalence of Human Immunodeficiency Virus (HIV) infection was $1.2 \%$ in the Democratic Republic of Congo, according to the Demographic Health Study report in 2014. In 2012, the severe failure rate to first-line ART in Kinshasa was estimated at more than $16 \%$. Objective: The objective of this study is to determine the rate of clinical, immunological and virological failure in first-line treatment in Kinshasa. Methodology: At the 6th month of Antiretroviral Treatment (ART), 138 patients from a follow-up cohort of 8 centers in Kinshasa were received for paraclinical evaluations and analyses. The clinical and paraclinical parameters were recorded on the individual patient sheets as well as the survey forms. Clinical parameters, viral load and CD4 were evaluated at the 6th month of ART. Results: One hundred and thirty-eight (138) patients had returned for follow-up treatment, 81 women and 57 men. The average age of patients is $37 \pm 12$ years. The dominant age groups are those of 26 to 35 years and 36 to 45 years with 39 patients (28.3\%) each, followed by those of 18 to 25 years (21.7\%). One hundred and twenty-five (125) patients (90.5\%) were in clinical stage 3 and $13(9.5 \%)$ in clinical stage 4 according to the WHO classification. CD4 levels ranged from 98 to 1050 cells $/ \mathrm{mm}^{3}$ and a median value of 560 cells $/ \mathrm{mm}^{3}$. The median value of the patients' VLs was $0.90 \log _{10}$ copies of RNA/ml with respective minimum and maximum values of 0 and 4.82 $\log _{10}$ copies of $\mathrm{RNA} / \mathrm{ml}$. The virological failure rate was $24.6 \%$. Conclusions: The rate of virological failure of first-line antiretroviral treatment of patients under treatment in Kinshasa is $24.6 \%$ for the year 2015.
\end{abstract}

\section{Subject Areas}

HIV 


\section{Keywords}

Treatment Failure, HIV, Kinshasa

\section{Introduction}

To date, the Human Immunodeficiency Virus (HIV) remains a public health problem around the world. In 2014, the United Nations program to fight HIV and AIDS (UNAIDS) reports an average of 35.3 million (32.2 - 38.8 million) HIV-infected people worldwide and an average of 2.3 million (1.9 - 2.7 million) new cases for the year. Sub-Saharan Africa still bears the greatest burden of the global epidemic. Almost 2/3 (63\%) of all adults and children living with HIV in the world are in Sub-Saharan Africa. Nearly 1/3 (32\%) of all People Living with HIV (PLHIV) in the world are in Southern Africa and $34 \%$ of all deaths from Acquired Immune Depression Syndrome (AIDS) have occurred there [1].

The Democratic Republic of Congo (DRC) is one of the countries with stable prevalence for HIV infection. The prevalence of infection was $1.2 \%$ for the country according to the report of the Demographic Study of Health in 2014 (EDS-2014) [2].

The tri-therapy adopted since 2008 in the DRC for PLHIV is a combination of 2 Nucleoside Inhibitors of Reverse Transcriptase (NRTI) and 1 Non-Nucleoside Reverse Transcriptase Inhibitor (NNRTI) as a first-line treatment [3]. The most used first-line molecules in Kinshasa are Didanosine (ddI), Lamivudine (3TC), Stavudine (d4T) and Zidovudine (ZDV or AZT), as well as Nevirapine (NVP) and Efavirenz (EFV) [3] [4].

In 2012, the rate of primary first-line ART failure in Kinshasa was estimated at more than $16 \%$ [5]. Therapeutic failure brings together a wide range of situations; it can be clinical failure, immunological failure with persistence of an immune deficiency or virological failure resulting from persistent viral replication under treatment [6] [7] [8].

The objective of this work is to determine the clinical, immunological and virological failure rate at first-line treatment in Kinshasa.

\section{Methods}

The present study is a cross-sectional evaluation at the $6^{\text {th }}$ month of treatment on a patient follow-up cohort. One hundred and fifty-three patients were randomly selected from 8 centers in Kinshasa from August 1, 2013 to February 28, 2014. At $6^{\text {th }}$ month of antiretroviral treatment, 138 patients were received for the assessments and analyzes of the parameters. The first-line treatment used for all patients was a combination of Zidovudine (ZDV), Lamivudine (3TC) and Nevirapine (NVP) which is the most available combination in the different treatment centers in Kinshasa. 


\subsection{Clinical and Biological Monitoring}

The clinical parameters were taken from the individual patient files in their respective centers as well as from the survey forms. The determination of the Viral Load (VL) was made at the Laboratory of Molecular Biology of the Faculty of Medicine of the University of Kinshasa (UNIKIN) using the same in-house assay used at inclusion [9] [10] [11]. The CD4 T-cells count was done using the Fascount under the same conditions as at day 0 .

\subsection{Comparison of Variables}

The clinical and laboratory parameters of the $6^{\text {th }}$ month of treatment were compared with those collected at the beginning of the cohort at baseline [12] [13] to determine the outcome of patients on the treatment. For compliance, the clinical endpoints were evaluated according to the World Health Organization (WHO) classification; and paraclinical examinations were performed in the same laboratories and the same conditions.

\subsection{Statistics}

Pearson correlation test was used to analyze the data. The probability value $p<$ 0.05 was considered as significant. The Viral Load was expressed in logarithmic decimal RNA copies/ml.

\subsection{Operational Definitions [6] [7] [8]}

Clinical failure to treatment is based on the reoccurrence of opportunistic infections and/or progression to a higher clinical stage (as recommended by the WHO) after the start of treatment, as well as the lost of weight of patient in a context without stress problem and reconstruction syndrome.

Immunological failure to treatment is defined by the absence of increased CD4 T-cells count despite effective ARV therapy for at least 6 months. This is seen more frequently in patients with initially low CD4 cell counts. As a general rule, a CD4 count below 200 cells $/ \mathrm{mm}^{3}$ is an indicator of immunological failure.

Virological failure to treatment is defined as a persistence VL greater than 200 copies of RNA/ml (2.30 $\log _{10}$ RNA copies/ml) 6 months after the start of treatment. Three definitions are presented for virological failure: 1) minimal failure ( $200<\mathrm{VL}<5000$ or $2.30 \log _{10}<\mathrm{VL}<3.70 \log _{10}$ RNA copies/ml), 2) moderate failure $\left(5000<\mathrm{VL}<30,000\right.$ or $3.70 \log _{10}<\mathrm{VL}<4.48 \log _{10}$ RNA copies $\left./ \mathrm{ml}\right)$ and 3) major or severe failure (VL $>30,000$ or $\mathrm{VL}>4.48 \log _{10}$ RNA copies $/ \mathrm{ml}$ ).

\section{Results}

One hundred and thirty-eight (138) patients returned for follow-up treatment control at the $6^{\text {th }}$ month. Eighty-one patients were women (Table 1), giving here a sex-ratio $\mathrm{M} / \mathrm{F}$ of 0.70 . The age of the patients ranged between 18 and 65 years with an average of $37 \pm 12$ years (Table 1 ). The dominant age groups are those aged 26 to 35 and 36 to 45 years old, with 39 patients (28.3\%) each, followed by 
those aged 18 to $25(21.7 \%)$, aged 46 to $55(16.7 \%)$ and 56 to 65 years $(5.1 \%)$.

\subsection{Clinical and Biological Data at Baseline (D0)}

At baseline, 140 patients (91.5\%) were in clinical stage 3 and 13 (8.5\%) in clinical stage 4 for HIV infection according to the WHO classification [13]. CD4 T-cells counts were between 8 and 915 cells $/ \mathrm{mm}^{3}$ with 69 patients (86.8\%) with CD4 count below 500 cells $/ \mathrm{mm}^{3}$ [12] [13]. The median VL value of the included patients was $5.68 \log _{10}$ RNA copies/ml [12] [13]. The minimum and maximum VL values were respectively $0.37 \log _{10}$ and $7.95 \log _{10}$ RNA copies/ml with 97 patients (63.4\%) having a VL greater than $100,000 \mathrm{RNA}$ copies/ml or $5.0 \log _{10}$ copies $\mathrm{RNA} / \mathrm{ml}$ [12] [13].

\subsection{Clinical and Biological Data at $6^{\text {th }}$ month (M6)}

At $6^{\text {th }}$ month, 125 patients, or $90.5 \%$, were in clinical stage 3 and $13(9.5 \%)$ in clinical stage 4 according to the WHO classification. CD4+ T-cell counts, which were performed on 113 patients (71\%), ranged from 98 to $1050 \mathrm{cells} / \mathrm{mm}^{3}$ with 52 patients (46.02\%) with CD4 counts greater than 500 cells $/ \mathrm{mm}^{3}$ and median of 560 cells $/ \mathrm{mm}^{3}$ (Table 1). The median VL value of the patients was $0.90 \log _{10}$ RNA copies/ml. The minimum and maximum values were respectively 0 and $4.82 \log _{10}$ RNA copies/ml with 104 patients (75.4\%) having a VL less than 200 RNA copies/ml or $2.3 \log _{10}$ RNA copies/ml thus giving a virological failure rate of $24.6 \%$ (Table 2). Of the 34 patients with virological failure, 8 (23.5\%) were in minimal failure $\left(2.30 \log _{10}<\mathrm{VL}<3.70 \log _{10}\right.$ RNA copies/ml), 23 (67.7\%) had moderate failure $\left(3.70 \log _{10}<\mathrm{VL}<4.48 \log _{10}\right.$ copies of RNA/ml) and $3(8.8 \%)$ in severe failure (VL $>4.48 \log _{10}$ RNA copies $/ \mathrm{ml}$ ) (Table 2).

Table 1. Characteristics of patients.

\begin{tabular}{|c|c|}
\hline Characteristics & Patients \\
\hline \multicolumn{2}{|c|}{$\operatorname{Sex}(n=138)$} \\
\hline Male & $57(41.3 \%)$ \\
\hline Female & $81(58.7 \%)$ \\
\hline \multicolumn{2}{|c|}{ Age (years) $(n=138)$} \\
\hline Interval & $18-65$ \\
\hline Mean & $37 \pm 12$ \\
\hline $18-25$ & $30(21.7 \%)$ \\
\hline $26-35$ & $39(28.3 \%)$ \\
\hline $36-45$ & $39(28.3 \%)$ \\
\hline $46-55$ & $23(16.7 \%)$ \\
\hline $56-65$ & $7(5.1 \%)$ \\
\hline \multicolumn{2}{|c|}{ Viral Load $\left(\log _{10}\right.$ RNA copies $\left./ \mathrm{ml}\right)(\mathrm{n}=138)$} \\
\hline Interval & $0-4.82 \log _{10}$ \\
\hline
\end{tabular}




\begin{tabular}{lc}
\hline Median & $0.90 \log _{10}$ \\
\multicolumn{2}{c}{ CD4 T-cells count (Cells/ml) $(\mathbf{n}=113)$} \\
Interval & $98-1050$ \\
Median & 480 \\
\hline
\end{tabular}

Table 2. Virological failure.

\begin{tabular}{|c|c|c|}
\hline Characteristics & \multicolumn{2}{|c|}{ Frequencies } \\
\hline Treatment success $C V<2.30 \log _{10}$ & \multicolumn{2}{|c|}{$104(75.4 \%)$} \\
\hline Treatment failure $C V>2.30 \log _{10}$ & \multicolumn{2}{|c|}{$34(24.6 \%)$} \\
\hline \multicolumn{3}{|c|}{ Failure by age group (years) } \\
\hline & $<2.30 \log _{10}$ & $>2.30 \log _{10}$ \\
\hline $18-25$ & $18(17.3 \%)$ & $12(35.3 \%)$ \\
\hline $26-35$ & $31(29.8 \%)$ & $8(23.5 \%)$ \\
\hline $36-45$ & $31(29.8 \%)$ & $8(23.5 \%)$ \\
\hline $46-55$ & $19(18.3 \%)$ & $4(11.8 \%)$ \\
\hline $56-65$ & $5(4.8 \%)$ & $2(5.9 \%)$ \\
\hline Total & 104 & 34 \\
\hline \multicolumn{3}{|c|}{ Type of virological failure } \\
\hline Minimal failure $\left(2.30<C V<3.70 \log _{10}\right)$ & \multicolumn{2}{|c|}{$8(23.5 \%)$} \\
\hline Moderate failure $\left(3.70<C V<4.48 \log _{10}\right)$ & \multicolumn{2}{|c|}{$23(67.7 \%)$} \\
\hline Severe failure $\left(C V>4.48 \log _{10}\right)$ & \multicolumn{2}{|c|}{$3(8.8 \%)$} \\
\hline
\end{tabular}

\section{Discussion}

The aim of this work was to determine the clinical, immunological and virological failure rate at treatment in Kinshasa.

After 6 months of ART, of the 138 patients (90.2\%) who returned for their control, 81 (58.7\%) patients were women and 57 (41.3\%) were men, which give a sex ratio $\mathrm{M} / \mathrm{F}$ of 0.70 . Various studies in our community have also published similar M/F sex ratios that tend to feminize HIV infection in adults in Sub-Saharan Africa [10] [14] [15] [16].

According to WHO recommendations, 125 patients, or $90.5 \%$, were in clinical stage 3 and 13 (9.5\%) in clinical stage 4 after 6 months of treatment. Whereas at the inclusion, $91.5 \%$ were in clinical stage 3 and $8.5 \%$ in clinical stage 4 [13]. This difference is not significant. Clinically, the clinician did not register much sign of deterioration of the state on the different patients during the different visits. Clinical stages are a function of the clinical signs recorded by clinicians during different visits to the patient [3].

CD4 T-cells counts were performed in 113 patients (71\%). The minimum and maximum CD4 T-cells counts were 98 and 1050 cells $/ \mathrm{mm}^{3}$, respectively. The median CD4 value is 560 cells $/ \mathrm{mm}^{3}$ of which 52 patients (46.02\%) with CD4 
counts greater than 500 cells $/ \mathrm{mm}^{3}$. It was not possible to determine immunological failure based on CD4 count because of the irregularity of this parameter in patients. Nevertheless, of all the patients who have the results at baseline and at the 6th month, none were in immunological failure because CD4 values have increased for all. The median difference in CD4 levels at month 6 from baseline $(\triangle \mathrm{CD} 4)$ was $247.5 \mathrm{cells} / \mathrm{mm}^{3}$. This brings us back to the issue of tracking people living with HIV/AIDS (PLHIV) in our environment [4] [16]. The biological parameters, not being supported in the free treatment, are the responsibility of the patients. This implies that these parameters are very often neglected and not present in patient records [4] [16].

The median VL value of the included patients was $0.90 \log _{10}$ RNA copies $/ \mathrm{ml}$. The minimum and maximum values were respectively 0 and $4.82 \log _{10}$ RNA copies/ml with 104 patients (75.4\%) having a VL less than $200 \mathrm{RNA}$ copies $/ \mathrm{ml}$ or $2.3 \log _{10}$ RNA copies/ml thus giving a virological failure rate of $24.6 \%$. Of the 34 patients with virological failure, 8 (23.5\%) had minimal failure $\left(2.30 \log _{10}<\mathrm{VL}<\right.$ $3.70 \log _{10}$ RNA copies/ml), 23 (67.7\%) had moderate failure $\left(3.70 \log _{10}<\mathrm{VL}<\right.$ $4.48 \log _{10}$ copies of RNA/ml) and $3(8.8 \%)$ in severe failure (VL $>4.48 \log _{10}$ RNA copies $/ \mathrm{ml}$ ). Most failed patients (67.7\%) have moderate virological failure. In the past, the virological failure was estimated at $14.6 \%$ in 2011 by Muwonga and all [17] and 16\% in 2012 by Kamangu and all [14] for Kinshasa, taking into account 3 clinics of referenced structure of the time. The difference in numbers lies in the criteria for inclusion of patients and selection of centers; as well as the scale of determination of treatment failure. Indeed, treatment failure was redefined as a $\mathrm{VL}>200$ copies of RNA/ml (2.3 $\log _{10} \mathrm{RNA}$ copies/ml) in 2013 [8] as opposed to a VL $>1000$ copies of $\mathrm{RNA} / \mathrm{ml}\left(3.0 \log _{10}\right.$ RNA copies/ml) from previous years [6]. In this work, 8 centers that meet the criteria according to WHO recommendations were randomly selected in order of 2 per district in Kinshasa [4]. Eight treatment and PLHIV monitoring centers participated in this work. For Kinshasa, according to the updated criteria, the virological failure rate was estimated at $24.6 \%$ for 2015.

\section{Conclusion}

The virological failure rate of first-line antiretroviral treatment of patients on treatment in Kinshasa is estimated at 24.6\% for the year 2015.

\section{Conflict of Interest}

The author declares that there was no conflict of interest.

\section{References}

[1] ONUSIDA. (2015) Rapport Mondial: Rapport ONUSIDA sur l'épidémie mondiale du SIDA en 2015.

[2] (2014) Ministère du Plan et Suivi de la Mise en œuvre de la Révolution de la Modernité et Ministère de la Santé Publique, République Démocratique du Congo. Enquête Démographique et de Santé 2013-2014: Rapport Annuel Préliminaire sur la 
Prévalence du VIH.

[3] (2013) Programme National de la Lutte contre le Sida et les IST (PNLS), Ministère de la Santé Publique, République Démocratique du Congo. Guide National de Traitement de l'infection à VIH par les antirétroviraux chez l'adolescent et l'adulte.

[4] Kamangu, N.E., Kalala, N.H. and Mesia, K.G. (2012) Profile of Antiretroviral Treatment Centers in Kinshasa, Democratic Republic of Congo. Proceedings of the 1 st Conference of the African Society of Laboratory Medicine, Poster 388.

[5] Kamangu, N.E., Kawila, M.E., Mukumbi, H. and Mvumbi, L.G. (2012) Estimated Rates of Treatment Failure in First-Line Antiretroviral Treatment in Kinshasa: Case of ACS AMO-CONGO. International Journal of Collaborative Research on Internal Medicine and Public Health, 4, 885-891.

[6] Yéni, P. (2010) Prise en charge médicale des personnes infectées par le VIH. Recommandations du groupe d'Experts. Paris, France. Médecine Sciences, Flammarion.

[7] Delfraissy, J.F. (2006) Prise en charge thérapeutique des personnes infectées par le VIH. Rapport 2004. Médecine-Sciences, Flammarion, Paris, France.

[8] Morlat, P. (2013) Prise en Charge Médicale des Personnes Vivant avec le VIH: Recommandations du Groupe d'experts. Sous l'égide du CNS et de l'ANRS, Rapports.

[9] Kamangu, N.E., Chatte, A., Boreux, R., Kalala, L.R., Mvumbi, L.G., De Mol, P., Vaira, D. and Hayette, M.P. (2014) Implementation of an In-House Quantitative Real-Time PCR for Determination of HIV Viral Load in Kinshasa. Open Access Library Journal, 1, e855.

[10] Kamangu, N., Chatte, A., Boreux, R., Kalala, L.R., Mvumbi, L.G., Vaira, D. and Hayette, M.P. (2014) Mise en place d'une PCR Quantitative Temps Réel pour la détermination de la Charge Virale VIH à Kinshasa. Journal des Recherches Biomédicales, 1, 7-12.

[11] Kamangu, N.E., Chatte, A., Boreux, R., Susin, F., Kalala, L.R., Mvumbi, L.G., De Mol, P., Hayette, M.P. and Vaira, D. (2015) Comparison of an In-House Quantitative Real Time PCR and COBAS AmpliPrep/TaqMan Roche for Determination of Viral Load for HIV Type 1 Non-B. Open Access Library Journal, 2, e1402.

[12] Kamangu, N.E., Chatte, A., Susin, F., Boreux, R., Kalala, L.R., Mvumbi, L.G., De Mol, P., Vaira, D. and Hayette, M.P. (2015) Genetic Diversity and Antiretroviral Drug Resistance among Drug-Naïve HIV Type 1 Infected Patients attending Clinics in Kinshasa, Democratic Republic of Congo. Journal of HIV and AIDS, 1, 1.

[13] Kamangu, N.E., Bulanda, I.B., Bongenia, I.B., Botomwito, T.H., Mvumbi, L.G., Hayette, M.P. and Kalala, L.R. (2015) Virological Profile of Patients Infected with HIV Starting Antiretroviral Treatment in Kinshasa. Open Access Library Journal, 2, e1564.

[14] Kamangu, N.E., Kawila, M.E., Mukumbi, H. and Mvumbi, L.G. (2012) Estimated Rates of Treatment Failure in First-Line Antiretroviral Treatment in Kinshasa: Case of the ACS AMO-Congo. International Journal of Collaborative Research on Internal Medicine and Public Health, 4, 885-891.

[15] Kamangu, N.E., Situakibanza, N.H., Mvumbi, L.G., Kakudji, I.L., Tshienda, T.D. and Mesia, K.G. (2012) Infections Opportunistes chez les Personnes Vivant avec le VIH suivi à l'Hôpital Militaire de Référence de Kinshasa (Camp Kokolo). Revue Congolaise des Sciences, 1, 66-76.

[16] Bongenya, B., Ilombo, L., Botomwito, H., Bulanda, B., Kamangu, E., Lusakibanza, 
M. and Mesia, G. (2014) Fréquence du Suivi des Paramètres Biologiques des Patients sous Antirétroviraux à Kinshasa: Cas de l'Hôpital Provincial Général de Référence. Journal des Recherches Biomédicales, 1, 1-6.

[17] Muwonga, J., Edidi, S., Butel, C., Vidal, N., Monleau, M., Okenge, A., Mandjo, J.L., Mukumbi, H., Muyembe, J.J., Mbayo, F., Kayembe, D., Delaporte, E., Boillot, F. and Peeters, M. (2011) Resistance to Antiretroviral Drugs in Treated and Drug-Naive Patients in the Democratic Republic of Congo. Journal of Acquired Immune Deficient Syndrome, 57, S27-S33.

\section{Abbreviation}

$3 T C$ : Lamivudine, $R N A$ : Ribose Nucleic Acid, $A R V$ : AntiRetroViral, $V L$ : Viral Load, $d 4 T$ : Stavudine, ddI: Didanosine, EDS: Demographic Health Study, EFV: Efavirenz, NNTRI: Non-Nucleoside Transcriptase Reverse Inhibitor, NTRI: Nucleoside Reverse Transcriptase Inhibitor, PI: Protease Inhibitor, NVP: Nevirapine, WHO: World Health Organization, UNAIDS: United Nations Organization for the Fight against HIV/AIDS, PLHIV: Person Living with HIV, DRC: Democratic Republic of Congo, AIDS: Acquired Immune Deficiency Syndrome, ART: AntiRetroViral Treatment, UNIKIN: University of Kinshasa, HIV: Human Immunodeficiency Virus, $Z D V$ : Zidovudine. 